\title{
CENTRINIŲ VENŲ KATETERIZACIJA OPERACINĖJE IR JOS SĄSAJA SU KRAUJO INFEKCIJOMIS
}

\author{
Raimonda Žiogaitė ${ }^{1}$, Šarlota Guzovijūtè ${ }^{1}$, Andrius Macas ${ }^{2}$ \\ ${ }^{1}$ Lietuvos sveikatos mokslu universiteto Medicinos akademijos Medicinos fakultetas, \\ ${ }^{2}$ Lietuvos sveikatos moksly universiteto Anesteziologijos ir reanimatologijos klinika
}

Raktažodžiai: kateteris, infekcija, centrinè vena, kateterizacija.

\begin{abstract}
Santrauka
Centrinès venos kateterizacija yra neatsiejama šiuolaikinès medicinos bei pacientų gydymo ir priežiūros dalis. Atliekant venų kateterizaciją galima ne tik padèti pacientui, bet ir sukelti mirtiną bei pavojingą komplikaciją - sepsị. Straipsnyje aptariami centrinès venos kateterizacijos ypatumai, kateterių tipai, dažniausiai pasirenkamos kateterizacijos vietos bei sepsio išsivystymo dažnis po šios procedūros. Taip pat bandoma atrasti sąsajas tarp gretutinių ligų bei infekcijos išsivystymo dažnio.

Tikslas. Ivertinti centrinès venos kateterizavimo ypatumus bei rizikos veiksnius komplikacijoms vystytis, nustatyti, ar Anesteziologijos klinikos gydytojų atliekamos kateterizacijos turi įtakos kraujo infekcijos išsivystymui.

Darbo metodika. Perspektyvusis, stebimasis klinikinis tyrimas, i kurị buvo ịtraukti LSMUL KK Chirurgijos skyriaus pacientai, kuriems nuo $2015 \mathrm{~m}$. rugsèjo mèn. iki $2016 \mathrm{~m}$. sausio mèn. operacijų metu buvo taikyta centrinès venos kateterizacija.

Išvados. Nustatyta, jog LSMUL KK Anesteziologijos klinikoje dažniausia centrinès venos kateterizacijos vieta - vidine jungo vena ir dažniausiai naudojami vienkanalio tipo kateteriai. Vidutinè centrinès venos kateterio laikymo trukmé buvo 7 dienos, o ją ilginančių veiksnių, susijusių su onkologinèmis ir neonkologinèmis ligomis, nustatyti nepavyko.
\end{abstract}

\section{Ivadas}

Centrinès venos kateterizacija yra viena iš sudedamujų modernios sveikatos priežiūros dalių visame pasaulyje, leidžianti užtikrinti parenterinę mitybą, hemodinamikos stebèjimą ir vertinimą, pakaitinę inkstų terapiją, skysčių bei kraujo produktų infuzijų taikymą bei medikamentų skyrimą. Tačiau nepaisant visų centrinès venos kateterizacijos privalumų, literatūros duomenimis, šie kateteriai yra viena iš kraujo infekcijos išsivystymo priežasčių $[1,2]$.

Bakteriemija - tai bakterijų buvimas kraujyje, kurios etiologija net 90 proc. atvejų susijusi su centrinès venos kateteriais. Ši diagnozè nustatoma remiantis klinikiniais simptomais ir požymiais, tokiais kaip karščiavimas $\left(>38^{\circ} \mathrm{C}\right)$ bei patogenų radimu ne mažiau kaip viename kraujo pasèlyje, kuris sutaptų su centrinio kateterio pasèlio rezultatu [3].

Infekcijos rizika didejja kateterio ịleidimo metu, jeigu nepakankamai akcentuojamos aseptikos ir antiseptikos taisyklès ir mikroorganizmai patenka ant išorinio ar vidinio kateterio paviršių. Taip pat mikroorganizmai gali atsirasti po kateterio įleidimo dèl atliekamų ịvairių manipuliacijų, kai kateteris laikomas per ilgai, laiku nepakeičiamas ar nepašalinamas [2]. Tai gali sukelti pavojingą infekciją - sepsị bei padidinti mirštamumą, pailginti pacientų gydymosi ligoninèje laiką, tai lemia padidèjusias gydymosi išlaidas.

Kraujo infekcijos išsivystymą gali lemti ir pasirinkta centrinès venos punkcijos bei kateterizacijos vieta. İvairių publikacijų duomenimis, dažniausiai gydytojai anesteziologai pasirenka vidinès jungo venos (90 proc.), antroje vietoje - poraktikaulinès, trečioje - šlaunies venos kateterizavimą [4]. Dažniausiai kateteriai ịkišami i jungo veną dèl geresnio prieinamumo ir mažesnès komplikacijų rizikos $[5 ; 6]$. Šlaunies venos kateterizavimas yra siejamas su didesne infekcijos išsivystymo rizika, todèl ši metodika pasirenkama rečiau.

Centrinès venos kateteriai naudojami skysčių, medikamentų, maisto medžiagų, kraujo produktų patekimo i paciento sisteminę kraujotaką užtikrinti. Net 90 proc. iš visų su kateteriais susijusių infekcijų siejama su centrinès venos kateteriais [7]. Ilgas kateterio naudojimas gali didinti infekcijos išsivystymo riziką, literatūroje galima sutikti rekomendacijų, kad centrinès venos kateteriai turi būti keičiami kas 96 valandas ar mažiausiai kartą per septynias dienas [2]. Neįrodyta, kad dažnas kateterio keitimas gali būti siejamas su padidejjusia kraujo infekcijos išsivystymo rizika, todèl rekomendacijų apie minimalią kateterio laikymo trukmę nèra. Ankstesnių publikacijų duomenimis, jei 
centrinès venos kateteris laikomas trumpiau nei tris dienas, tikimybė išsivystyti infekcijai lygi beveik 0 proc., jei kateteris laikomas iki 7 dienų, rizika padidejja iki $3-5$ proc., o jei ilgiau nei 7 dienas, rizika padidejja net iki 10 proc.[8].

Kraujo infekcijos, susijusios su centrinès venos kateterizacija, išsivystymo riziką didina ne tik anesteziologų galimai pažeidžiamos aseptikos ir antiseptikos taisyklès, bet ir gretutinès pacientų būklès - lètinès ligos, kaulų čiulpų transplantacija, imunodeficitinès būklès, onkologinès patologijos, cukrinis diabetas, anemija, vyresnis pacientų amžius, moteriška lytis ir kt. [9,7].

Perspektyvusis, stebimasis, klinikinis tyrimas atliktas Lietuvos sveikatos mokslų universiteto ligoninejje Kauno klinikose, Anesteziologijos klinikoje, gavus Lietuvos sveikatos mokslų universiteto bioetikos leidimą Nr. BECMF-05.

Tyrimas buvo atliekamas nuo $2015 \mathrm{~m}$. rugsèjo iki 2016 m. sausio ménesio. Tyrime dalyvavo chirurgijos skyriaus pacientai, kuriems stebimuoju laikotarpiu anesteziologai ar Anesteziologijos klinikos rezidentai ịkišdavo centrinès venos kateterius. Pacientai tyrimui buvo parenkami neatsižvelgiant ị jų amžių, lytị ir ligas. İ tyrimą įtrauktų ir atmestų pacientų kriterijai pateikti 1 lentelèje.

Iš viso ị tyrimą ịtraukti 59 pacientai, iš kurių du ị vèlesnị tyrimo etapą nepateko, nes dèl sunkios būklès neišgyveno iki stebejimo laikotarpio pabaigos. Pacientai buvo stebimi nuo kateterio ịleidimo iki jo ištraukimo dienos. Šiuo laikotarpiu buvo vertinamas jų arterinis kraujo spaudimas, širdies susitraukimų dažnis, temperatūra, kraujo rodikliai (eritrocitų, leukocitų, neutrofilų kiekis, CRB koncentracija kraujo plazmoje), kraujo bei kateterio pasèliai, lokalūs infekcijos požymiai aplink ịkišimo vietą (paraudimas, hematoma, patinimas, temperatūra, skausmingumas). Buvo registruojama kateterio ileidimo vieta bei tipas. Papildoma informacija apie pagrindinę bei gretutines ligas, tokias kaip onkologinès patologijos, lètinès ligos, cukrinis diabetas, anemija, imunodeficitinès būklès, surinkta iš medicininès dokumentacijos.

Duomenų analizė buvo atlikta naudojant „Microsoft

1 lentelè. İ tyrimą ịtrauktų ir atmestų pacientų kriterijai

\begin{tabular}{|l|c|}
\hline Itraukimo kriterijai & Atmetimo kriterijai \\
\hline Sutikimas dalyvauti & Nesutikimas dalyvauti \\
\hline Amžius $>18 \mathrm{~m}$. & Amžius $<18 \mathrm{~m}$. \\
\hline $\begin{array}{l}\text { Ileistas centrinès venos } \\
\text { kateteris }\end{array}$ & \\
\hline $\begin{array}{l}\text { Chirurgijos skyriaus } \\
\text { pacientai }\end{array}$ & \\
\hline $\begin{array}{l}\text { Kateteris įleistas opera- } \\
\text { cinëje }\end{array}$ & \\
\hline
\end{tabular}

Office Excell 2007“ programą. Kiekybinių rodiklių duomenys pateikiami apskaičiavus vidurkį, kokybiniai rodikliai pateikiami procentine išraiška.

Stebimų pacientų atvejais buvo taikoma standartizuota anestezijos metodika, o kateteriai buvo įleidžiami laikantis visų sterilumo reikalavimų. Pacientui atvykus ị pooperacinę palatą jie buvo iš karto registruojami į tyrimą, norint kuo tiksliau stebèti galimą infekcijos progresavimą.

Duomenys buvo registruojami kiekvieną dieną iki kateterio ištraukimo. Pacientai, kurie buvo perkelti iš chirurgijos skyriaus ị kitą, tačiau vis dar turèjo kateterị, ir toliau buvo stebimi.

\section{Rezultatai}

Atliktame tyrime dalyvavo 57 pacientai, kuriems buvo ikišti centrinès venos kateteriai. Tiriamieji buvo pasirenkami atsitiktinai, neatsižvelgiant ị jų amžių, lytį, esamas ligas, operacijos tipą. Duomenys buvo fiksuojami specialiuose tyrimo protokoluose (anketose).

Visų pacientų amžiaus vidurkis buvo $66,02 \pm 12,28$ metai. Amžiaus ribos svyravo nuo 36 iki 89 metų. Didžiają dali tiriamujų sudare vyrai. Nustatyta, kad 49 (85 proc.) kateteriai buvo įleisti i jungo veną ( 2 lentelè.). Pagal kateterių tipą dažniausiai buvo naudojamas vienkanalis kateteris. Tai sudare 33 atvejus ( 58 proc.) iš visų tiriamųųu. Antroje vietoje buvo naudojamas dvikanalis (19; 33 proc.), o trečioje - trikanalis kateteriai (5; 8 proc.). Paminètina, jog net 30 (52 proc.) centrinès venos kateterių buvo įleisti gydytojų rezidentų. Vidutinè kateterių laikymo trukmè buvo $6,98 \pm 5,05$ dienos. Sąsajos tarp šalutinių ligų ir infekcijos išsivystymo rizikos nusatyti nepavyko, tačiau vertinant rezultatus buvo pastebèta, kad 42 (73 proc.) iš visų kateterizuotų pacientu sirgo onkologinèmis ligomis. Tyrimo metu buvo vertinamas kraujo infekcijos išsivystymo dažnumas bei rizika, susijusi su anesteziologu ịkišamais centrinès ve-

2 lentelè. Pacientų charakteristika

\begin{tabular}{|l|c|}
\hline Charakteristika & $\mathbf{n ( \% )}$ \\
\hline Lytis & \\
\hline Vyrai & $19(66)$ \\
Moterys & $38(34)$ \\
\hline Kateterio tipas & \\
\hline Vienakanalis & $33(58)$ \\
Dvikanalis & $19(34)$ \\
Trikanalis & $5(8)$ \\
\hline Kateterio illeidimo vieta & \\
\hline v. jugularis interna & $49(86)$ \\
v. subclavia & $8(14)$ \\
\hline Onkologinės ligos & \\
\hline Yra & $42(74)$ \\
Nëra & $15(26)$ \\
\hline
\end{tabular}


nos kateteriais. Iš visų tyrime dalyvavusių asmenų kraujo infekcija išsivyste tik 1 pacientei, kuriai viso hospitalizavimo metu (84 lovadieniai) buvo atliktos kelios operacijos ir pakartotinès centrinès kateterizacijos. Vienas iš kateteriu buvo laikytas 33 dienas.

\section{Aptarimas}

Darbo tikslas buvo nustatyti, ar Anesteziologijos klinikos gydytojų ỉkišami centrinès venos kateteriai yra šaltinis išsivystyti kraujo infekcijai. Remiantis tyrimo rezultatais, galima daryti išvadą, jog anesteziologai, atlikdami centrinès venos punkciją ir kateterizaciją, laikosi visų būtinų aseptikos ir antiseptikos taisyklių, kadangi iš 57 pacientų infekcija išsivyste tik vienai pacientei. Tuo tarpu besivystančiose šalyse, tokiose kaip Indija, infekcijų, susijusių su centrinės venos kateteriais, dažnos, yra nuo trijų iki penkių kartų didesnès. Remiantis tyrimu, atliktu šiaurès Indijoje, i kurị buvo ịtraukti 153 pacientai, kuriems centrinès venos kateteriai buvo laikyti ilgiau nei 48 valandas, buvo nustatyti net 46 infekcijų atvejai [10].Tai ịrodo išsivysčiusių šalių pranašumą, kuomet centrinès venos kateterizacija yra atliekama pagal griežtai standartizuotą aseptikos ir antiseptikos protokolą, taip išvengiant infekcijų, susijusių su šiais kateteriais, paplitimo. Vis dèlto Anesteziologijos klinikoje atliktame tyrime buvo stebima 384 visų kateterių laikymo dienos, kai tuo tarpu vienoje iš Indijos ligoninių buvo tiriama net 2698 dienos. 2015 metais publikuotame straipsnyje Taivano ligoninès gydytojai paskelbè tyrimą, kuriame buvo vertinamas infekcijos išsivystymo dažnis, susijęs su centrinès venos kateteriu. Tyrimas buvo retrospektyvus ir jo rezultatai aprašomi nuo 2012 metų rugsejo iki 2013 metu gruodžio menesio. Tiriamuoju laikotarpiu diagnozuotas 31 teigiamas infekcijos atvejis. Tai atitinka 1,9 atvejo per mènesị [11]. Kraujo infekcijų rizikos problema dèl centrinès venos kateteriu aktuali ir kitose šalyse. Švedijos gydytojai atliko perspektyvų tyrimą vertindami infekcijų dažnį nuo 2004 iki 2009 metų. Tuo laikotarpiu buvo atliktos 2772 centrinès venos kateterizacijos, o infekcijos, susijusios su centriniais venos kateteriais sudare 0,6 atvejo stebimuoju laikotarpiu [12].

Verta paminèti, jog svarbus ne tik kateterizavimo laikas, tačiau ir pati ịleidimo vieta. 2016 metais publikuotame straipsnyje, daugelio šalių stebejjimų duomenimis, mažiausia rizika išsivystyti infekcijai yra kateterizuojant poraktikaulinę ar jungo venas [13]. Buvo vertinami 18554 centrinès venos kateteriai. Išvados parodè, jog poraktikaulines venos kateterizavimas sukelia mažiausiai komplikacijų ir galimybių išsivystyti infekcijai. Tokių tyrimo rezultatų iš atlikto tyrimo LSMUL KK Anesteziologijos klinikoje nustatyti nepavyko dèl mažos imties. Dažniausiai kateteriai buvo ịkišami ị vidinę jungo veną (49), rečiau ị poraktikau- linę veną (8), o šlaunies venos kateterizavimas tyrimo laikotarpiu nebuvo atliktas.

Be kateterio illeidimo vietos, ypatingas dèmesys buvo atkreiptas ị kateterio priežiūrą po procedūros, perrišimus ir kateterio keitimą. Daugumos stebètu pacientų kateterio laikymo trukmè buvo trumpa, siekè iki 7 dienų, todèl patys kateteriai nebuvo keičiami, perrišimai nebuvo atliekami. Pasitaike keli atvejai, kuomet po procedūros aplink kateterị, po pleistru, buvo kraujo. Medicinos personalas perrišimus atlikdavo kitą dieną po operacijos, procedūros būdavo atliekamos kruopščiai ir infekcijos požymių pacientams nepasireiškè. Buvo stebimi ir kateterių laikymo iki 10 dienų atvejai. Perrišimai nebuvo atliekami, kateteriai nekeisti, tačiau pacientams viso laikotarpio metu nebuvo pasireiškę jokie sisteminès infekcijos požymiai.

Mūsų atlikto stebimojo tyrimo metu buvo rastas vienas infekcijos, susijusios su centrinès venos kateteriu, atvejis. Ši pacientè buvo didelès rizikos grupeje. 59 metų amžiaus moteris sirgo gimdos kaklelio vèžiu, buvo rastas abscesas mažajame dubenyje, anemija, taikyta aktinoterapija. Gydymo eigoje pacientei susiformavo fistule tarp plonosios žarnos ir šlapimo pūslès, buvo nustatytas išsekimas ir intoksikacija naviko irimo produktais. Viso laikotarpio metu pacientei buvo atliktos keturios operacijos. Pradžioje taikyta laparotomija, susiūta šlapimo pūslè. Būklè blogejo, patvirtinus šlapimo pūslès fistulę atlikta diagnostiné laparotomija, plonosios žarnos ir šlapimo pūslès susiuvimas. Po operacijos būklè negerejo. Atlikta relaparotomija, buvo rasta a.iliaca externa uzūracija. Po ménesio pacientès būklei nesikeičiant taikytos pakartotinès chirurginės intervencijos, tačiau tai nesustabde tolesnio progresavimo. Moteris LSMUL KK gydèsi beveik tris mènesius, per kuriuos buvo atliktos trys centrinių venų kateterizacijos. Pirmasis kateteris buvo laikytas 9 dienas, ịleistas ị dešiniają vidinę jungo veną, antrasis kateteris buvo ịleistas i kairiają vidinę jungo veną ir laikytas kelias dienas, o trečiasis ị dešiniają v. subclavia ir laikytas net 33 dienas. Prieš trečiojo kateterio pašalinimą taip pat buvo stebimi vietiniai uždegimo požymiai: paraudimas, pakilusi odos temperatūra kateterio ịkišimo vietoje. Tai yra vieni iš pirmujų klinikinių simptomų, galinčių parodyti, kad centrinès venos kateteris yra kolonizuotas mikroorganizmų [14]. Pašalinus šị kateterį, buvo paimtas pasèlis, kuris sutapo su kraujo pasèliu. Buvo identifikuoti Stafilococus epidermidis ir Stafilococcus maltophilia sukelejjai. Antibiotikogramos duomenimis, pirmasis sukèlèjas buvo jautrus tik vankomicinui ir rifampicinui, o antrasis - sulfanilamidams. Skirtas antibakterinis gydymas imipenemu ir vankomicinu.

Pacientei dèl ligos ir gydymo eigoje atsiradusių daugybinių komplikacijų, taip pat taikyto spindulinio gydymo pasireiškè imuniteto susilpnèjimas ir potencialūs infekcijos 
vartais galimai tapo centrinès venos kateteris, kuris, tikètina, nebuvo laiku pašalintas ir nebuvo tinkamai prižiūrimas. Kadangi centrinès venos kateteris buvo laikytas 33 dienas, remiantis kitų publikacijų duomenimis, infekcijos išsivystymo tikimybè šiai pacientei padidèjo daugiau nei 10 proc., kas, manoma, ir lèmè teigiamus pasèlių rezultatus.

\section{Išvados}

LSMUL KK Anesteziologijos klinikoje dažniausia centrinès venos kateterizacijos vieta - vidiné jungo vena ir dažniausiai naudojami vienkanalio tipo kateteriai. Kraujo infekcija, susijusi su centriniu venos kateteriu, išsivyste tik vienai pacientei iš visų tiriamujų; jai kateteris buvo laikytas daugiau nei vieną mėnesį. Tvirtai teigti, jog anesteziologu ịkišami kateteriai negali būti infekcijos priežastis, būtų sudètinga dèl mažo tiriamųų skaičiaus.

\section{Literatūra}

1. Ling Lin M, Apisarnthanarak A, Jaggi N, Harrington G, Morikane K, Thu Anh Thi L, Ching P, Villanueva V, Zong Z, Jeong Sim J, Lee C. APSIC guide for prevention of central line associated blood stream infections (CLABSI). Antimicrobial resistance and infection control 2016; 5:16. https://doi.org/10.1186/s13756-016-0116-5

2. The Joint Commission. Preventing central line-associated blood stream infections: a global challenge, a global perspective. Oak Brook: Joint Commission Resources 2012.

3. Fagan R, Edwards J, Park B, Fridkin S, Magill S. Incidence trends in pathogen-specific central line-associated blood stream infections in US intensive care units 1990-2010. Infection Control And Hospital Epidemiology 2013; 9(34): 893-899. https://doi.org/10.1086/671724

4. Martı'nez-Morel H, Sa'nchez-Paya'a J, Molina-Go'mez M, Garci'a-Shimizu P, V, Garcı'aRoma'n V, Villanueva-Ruiz C, Gonza'lez-Herna'ndez M, Nolasco-Bonmatı A. Catheterrelated blood stream infection: burden of diseasein a tertiary hospital. Journal of Hospital Infection 2014; 87:165-170. https://doi.org/10.1016/j.jhin.2014.04.008

5. Nolan M, Yadav H, Cawcutt K, Cartin-Ceba R. Complication rates among peripherally inserted central venous catheters and centrally inserted central catheters in the medical intensive care unit. MD Journal of Critical Care 2016; 31:238-242.

https://doi.org/10.1016/j.jcrc.2015.09.024

6. Nama R, Bhosale G, Shah V. Idiopathic unilateral hypoplasia of internal jugular vein and coagulopathy: unusual case for central venous catheterization. Anesth Essays Res 2015; 9(3): 437-439. https://doi.org/10.4103/0259-1162.158012

7. Tao F, Jiang R, Chen Y, Chen R. Risk factors for early onset of catheter-related blood stream infection in an intensive care unit in China: a retrospective study. Med Sci Monit 2015; 21:550-556. https://doi.org/10.12659/MSM.892121
8. Dyer Eric L. Central venous catheter nursing care guidelines. Arrow International Inc 1996; 40.

9. Fram D, Okuno M, Taminato M, Ponzio V, Manfredi S, Grothe C, Belasco A, Sesso R, Barbosa D. Risk factors for blood stream infection in patients at a Brazilian hemodialysis center: a case-controlstudy. BMC Infectious Diseases 2015; 15:158. https://doi.org/10.1186/s12879-015-0907-y

10. Misraa S.B, Misrab R, Azima A, Baroniab A.K, Prasadb K.N, Dholeb T.N, Gurjara M, Singha R.K, Poddara B. Epidemiology of central line-associated blood stream infections at a tertiary care centre in northern India. Journal of Hospital Infection 2016; 92:295-302. https://doi.org/10.1016/j.jhin.2015.11.015

11. Chen X, Lo Y, Su L, Chang C. Investigation of the case numbers of catheter-related blood stream infection overestimated by the central line-associated blood stream infection surveillance definition. Journal of Microbiology, Immunology and Infection 2015; 6(48):625-631. https://doi.org/10.1016/j.jmii.2014.03.006

12. Hammarskjöld F, Berg S, Hanberger H, Taxbro K, Malmvall B. Sustained low incidence of central venous catheter-related infections over six years in a Swedish hospital with an active central venous catheter team. American Journal of Infection Control 2017; 2(42):122-128.

13. Kostoula A, Dimitrios L, Stijn B, Fani A, Despoina K, Bettina H. Cumulative evidence of randomized controlled and observational studies on catheter-related infection risk of central venous catheter insertion site in ICU Patients: a pair wise and network meta-analysis. Critical Care Medicine 2016.

14. Silvah J.H, Lima C.M, Unamuno M.R, Schetino M.A.A, Giácomo Fassini L.P.S, Costa C.F, Brandão C, Basile-Filho A, Cunha S.F.C, Marchini J.S. Body surface infrared thermometry in patients with central venous catheter-related infections. Einstein 2015; 13(3):364-9.

https://doi.org/10.1590/S1679-45082015AO3397

\section{INTERACTION BETWEEN CENTRAL VEIN CATHETERIZATION IN OPERATING THEATRE AND BLOOD INFECTION \\ R. Žiogaitè, Š. Guzovijūtè, A. Macas}

Key words: catheter, infection, central vein, catheterization. Summary

Central vein catheterization has an inseparable part for these days medicine. Likewise, it has an important part in pacients care. Inserting central vein catheter can help patients but it also can transmit a deadly infection - sepsis.

This article discuss particularities of central vein catheterization, the most common places of catheterization, all catheter types that are used the most and the rate of sepsis after this procedure. Dispite that, we will try to find interface between underlying diseases and the development rate of infection.

Correspondence to: s.guzovijute@gmail.com

Gauta 2017-02-21 